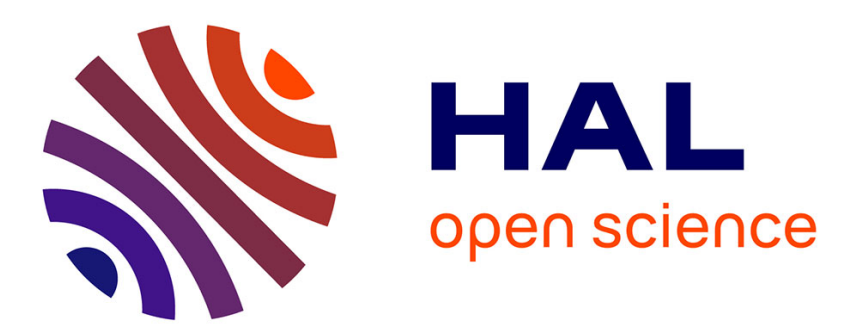

\title{
New Blue-Photoluminescent Semi-Conducting Polymer Derived from Fluorinated Bisphenol A
}

Nejmeddine Jaballah, Khaled Hriz, Mustapha Majdoub, Mohamed Jouini, Jean-Louis Fave

\section{- To cite this version:}

Nejmeddine Jaballah, Khaled Hriz, Mustapha Majdoub, Mohamed Jouini, Jean-Louis Fave. New Blue-Photoluminescent Semi-Conducting Polymer Derived from Fluorinated Bisphenol A. High Performance Polymers, 2010, 22 (4), pp.483-497. 10.1177/0954008309348664 . hal-01236810

\author{
HAL Id: hal-01236810 \\ https://hal.science/hal-01236810
}

Submitted on 14 Aug 2020

HAL is a multi-disciplinary open access archive for the deposit and dissemination of scientific research documents, whether they are published or not. The documents may come from teaching and research institutions in France or abroad, or from public or private research centers.
L'archive ouverte pluridisciplinaire HAL, est destinée au dépôt et à la diffusion de documents scientifiques de niveau recherche, publiés ou non, émanant des établissements d'enseignement et de recherche français ou étrangers, des laboratoires publics ou privés. 


\title{
New Blue-Photoluminescent Semi-Conducting Polymer Derived from Fluorinated Bisphenol A
}

\author{
NEJMEDDINE JABALLAH \\ KHALED HRIZ \\ MUSTAPHA MAJDOUB ${ }^{1}$ \\ Laboratoire des Polymères, Biopolymères et Matériaux Organiques (LPBMO), Faculté des \\ Sciences de Monastir, Bd. de l'Environnement, 5019 Monastir, Tunisia
}

\section{MOHAMED JOUINI}

Laboratoire Interfaces Traitements Organisations et Dynamique des Systèmes (ITODYS), Université Denis Diderot-Paris 7, 1 rue Guy de La Brosse, 75005 Paris, France

JEAN-LOUIS FAVE

Institut des NanoSciences de Paris (INSP), Université Paris 6 et 7 et CNRS, 140 rue de Lourmel, 75015 Paris, France

\begin{abstract}
A new confined p-phenylenevinylene (PPV)-type polymer (BPAF-PPV) has been synthesized using Wittig condensation. The chemical structure of the polymer was well defined by ${ }^{1} \mathrm{H}-\mathrm{NMR}$, ${ }^{13} \mathrm{C}-\mathrm{NMR}$, and FT-IR spectroscopic analysis. BPAF-PPV contains oligomeric PPV units separated by hexafluoroisopropylidene groups in the main chain; it is fully soluble in common organic solvents and has a number-average molecular weight of $4570 \mathrm{~g} \mathrm{~mol}^{-1}$. Differential scanning calorimetry indicates that BPAF-PPV is amorphous and displays a glass transition temperature of $114{ }^{\circ} \mathrm{C}$. The optical properties of the polymer were investigated by UV-visible absorption and photoluminescence spectroscopies. Its thin film showed a blue photoluminescence with a narrow emission spectrum. A high photoluminescence quantum efficiency of about $83 \%$ was determined in dilute solution. From the cyclic voltammetry analysis, the electrochemical bandgap was estimated to be $3.08 \mathrm{eV}$. A single-layer diode device of the configuration indium-tin oxide/BPAF-PPV/aluminium has been fabricated and has a relatively low turn-on voltage of $3.0 \mathrm{~V}$.
\end{abstract}

Key Words: Conjugated semi-conducting polymers, confined $p$-phenylenevinylene, blue photoluminescence, fluorinated bisphenol A 


\section{INTRODUCTION}

The discovery of electroluminescence in poly(p-phenylenevinylene) (PPV), in 1990 [1], has produced a new area in polymer sciences: the $\pi$-conjugated semi-conducting polymers. Since then, a tremendous progress has been made in the molecular engineering of conjugated polymers and in their uses as active components in polymeric light-emitting diodes (PLEDs) [2-4]. These organic materials are currently expanding their applications to others devices, such as light-emitting electrochemical cells [5, 6], thin-film transistors [7], solar cells [8,9] and chemical sensors [10,11]. Such light-emitting polymers have several potential advantages over electroluminescent inorganic materials in that singlepolymer-layer devices can be fabricated that exhibit low operating voltage, high emission quantum yield, mechanical strength, low weight, large display area and color tunability. Moreover, device fabrication can be simplified by the use of spin-coating or ink-jet printing techniques.

Full color display applications require red, green, and blue emission and while all three colors have been demonstrated there are relatively few blue-emitting polymers [12]. The first blue-PLED was made using poly(9,9-dihexylfluorene) [13]. Other blue-electroluminescent polymers have since been demonstrated, including 9,9-disubstituted polyfluorenes [14], polyphenylene derivatives [15], 3,4-disubstituted polythiophenes [16] and $\operatorname{poly}(m$-phenylenevinylene) derivatives [17]. PPV-type blue-emitting polymers can be obtained by a partial conversion of the precursor polymer in the sulfonium route to PPV, giving a high concentration of interruptions in the conjugated chain $[18,19]$. In a second way, introducing co-monomers with flexible linker groups into a step growth condensation route to PPV, can lead to blue-emitting copolymer [20]. However, these two methods only allow limited control of the length and the distribution of conjugated segments. Hence, the emission occurs usually from the more highly conjugated segments, and the emission spectrum is therefore broadened and red-shifted.

To solve this problem, the confinement of the conjugation into a well-defined length is one of the most successful developed strategies [3]. Some blue-emitting polymers, containing well-defined oligomeric PPV units separated with non-conjugated aliphatic spacer units in the polymer backbone, were reported [21, 22]. Such polymers usually exhibit good solubility. They are homogeneous in terms of conjugation length and show narrow emission spectra and high photoluminescence quantum yields in the solid state, due to exciton confinement and reduction of luminescence loss via the quenching processes caused by $\pi-\pi$ stacking of the conjugated moieties [23]. Nevertheless, the relatively long aliphatic segments, used as spacers in these polymers, can act as a barrier to injection and mobility of the charge carriers, resulting in higher turn-on voltages [2].

In our contribution in molecular engineering of blue-emitting PPVs, we follow the same confined-conjugation strategy, but using shorter spacer groups. In previously work, we have reported a PPV-type confined polymer derived from bisphenol A (scheme 1, BPA-PPV) [24]. This polymer, which contains the isopropylidene group as spacer, showed a low operating voltage. A blue emission and a narrow photoluminescence spectrum were obtained in BPA-PPV/chloroform solution. However, in thin film the emission was red- 

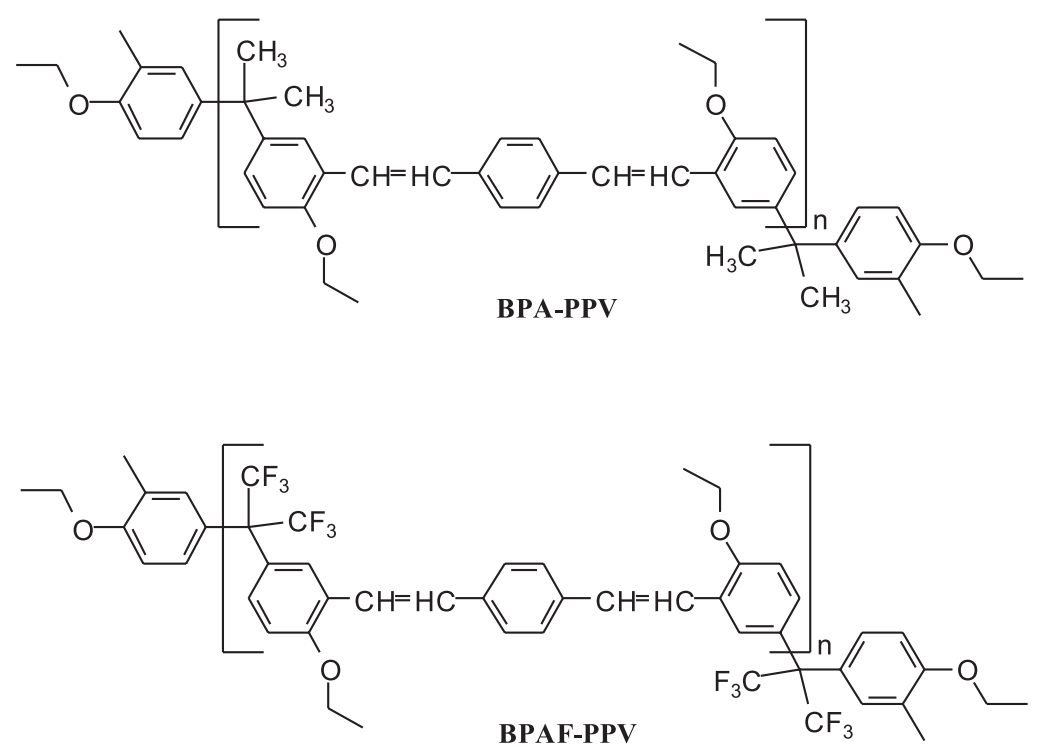

Scheme 1. BPA-PPV and BPAF-PPV structures.

shifted and the spectre was significantly broadened, due to $\pi-\pi$ stacking of the PPV segments. Introduction of bulky moieties in polymer backbone or as side groups, is one of the more useful methodologies to prevent $\pi-\pi$ stacking in conjugated polymer films [25, 26]. Herein, we follow the same approach. We report on the design, synthesis and characterization of a BPA-PPV fluorinated analogue. The new polymer has the same PPV-type conjugated unit, but contains the bulky hexafluoroisopropylidene group as spacer and $\pi-$ $\pi$ interaction preventing moiety (scheme 1, BPAF-PPV).

\section{EXPERIMENTAL}

\subsection{Materials and measurements}

4,4'-(Hexafluoroisopropylidene)diphenol (fluorinated bisphenol A, BPAF) (Acros, 97\%), bromoethane (Acros, 98\%), potassium carbonate (Acros, 99\%), paraformaldehyde (Acros, 96\%), triphenylphosphine (Acros, 99\%), terephthaldicarboxaldehyde (Aldrich, 99\%) and potassium tert-butoxide (Acros, $98 \%$ ) were used as received. Tetrahydrofuran (THF) was dried over $\mathrm{Na} /$ benzophenone and freshly distilled before use. Acetone was stirred over and distilled from potassium carbonate under argon. Other solvents were commercially available and were used without further purification. Melting points $(\mathrm{mp})$ were determined on an Electrothermal Mode 9100 digital analyzer and were not corrected. NMR spectral 
data were obtained on a Bruker AV 300 spectrometer. ${ }^{1} \mathrm{H}-\mathrm{NMR}$ and ${ }^{13} \mathrm{C}-\mathrm{NMR}$ chemical shifts are referenced to $\mathrm{CHCl}_{3}$ signal (7.26 ppm for ${ }^{1} \mathrm{H}, 77.16 \mathrm{ppm}$ for ${ }^{13} \mathrm{C}$ ). For ${ }^{19} \mathrm{~F}-\mathrm{NMR}$ spectrum, $\mathrm{CFCl}_{3}$ was used as an external standard $(0 \mathrm{ppm})$, and upfield shifts are reported as negative values. Signals associated with the $\mathrm{CF}_{3}$ groups and proximal quaternary center were not reported in the ${ }^{13} \mathrm{C}-\mathrm{NMR}$ data due to $\mathrm{C}-\mathrm{F}$ coupling and low signal-to-noise ratios. FTIR spectra were acquired on a Perkin-Elmer BX FTIR system spectrometer by dispersing samples in $\mathrm{KBr}$ disks. Thermogravimetric analysis (TGA) was carried out on a Setaram TG-DTA 92-10 thermal analyzer under ambient atmospheric conditions at a heating rate of $10{ }^{\circ} \mathrm{C} \mathrm{min}^{-1}$. DSC was performed on a Setaram instrumentation-regulation DSC 131 system with a heating rate of $10{ }^{\circ} \mathrm{C} \mathrm{min}-1$. UV-vis absorption spectra were recorded on a Cary 5000 UV-Vis-NIR spectrophotometer. Photoluminescence (PL) spectra were obtained on a Jobin-Yvon spectrometer HR460 coupled to a nitrogen-cooled Si charged-coupled device (CCD) detector. Samples were excited with a $450 \mathrm{~W}$ Xenon lamp at the corresponding absorption maximum. For solid state measurements, the films were spin coated onto a silica substrate from a $2 \times 10^{-2}$ mol L ${ }^{-1}$ chloroform solution. All measurements were performed at room temperature $\left(25^{\circ} \mathrm{C}\right)$. Cyclic voltammetry $(\mathrm{CV})$ was performed on an EG\&G model 273 potentiostat/galvanostat (Princeton Applied Research) in a three-electrode cell using polymer films that were drop-cast onto an indium tin oxide (ITO) as working electrode. The measurements were carried out at a scanning rate of $50 \mathrm{mV} \mathrm{s}^{-1}$ against a saturated calomel reference electrode (SCE) and using the tetrabutylammonium perchlorate $\left((\mathrm{n}-\mathrm{Bu})_{4} \mathrm{ClO}\right)$ in acetonitrile $\left(0.1 \mathrm{~mol} \mathrm{~L}^{-1}\right)$ as supporting electrolyte. The electrochemical cell was externally calibrated by a ferrocene standard. The measurements were performed at $25{ }^{\circ} \mathrm{C}$ and the cell was deoxygenated with argon before each scan.

\subsection{Synthesis of 2,2-bis(4-ethoxyphenyl)hexafluoropropane (BPAFEt)}

To a stirred mixture of BPAF (3.46 g, $10 \mathrm{mmol}$ ) and potassium carbonate $(3.48 \mathrm{~g}$, $25 \mathrm{mmol})$ in $20 \mathrm{~mL}$ of dimethylformamide, was added dropwise bromoethane $(2 \mathrm{~mL}$, $26 \mathrm{mmol})$. After stirring for $8 \mathrm{~h}$ at room temperature $\left(25^{\circ} \mathrm{C}\right)$, the reaction mixture was poured into distilled water and extracted with diethyl ether. The extract was washed with distilled water, dried over anhydrous magnesium sulfate, and then evaporated. The resultant crude product was purified by recrystallization from ethanol/water (3/1) to afford BPAFEt as white crystals. Yield: $92 \%$; mp: $44{ }^{\circ} \mathrm{C} ;{ }^{1} \mathrm{H}-\mathrm{NMR}\left(300 \mathrm{MHz}, \mathrm{CDCl}_{3}, \delta\right)$ : $7.31(\mathrm{~d}, \mathrm{~J}=8.7 \mathrm{~Hz}, 4 \mathrm{H}, \mathrm{Ar}-\mathrm{H}), 6.87$ (d, J = 8.7 Hz, 4H, Ar-H), 4.05 (q, J = 6.9 Hz, 4H, $\left.\mathrm{OCH}_{2}\right), 1.43\left(\mathrm{t}, \mathrm{J}=6.9 \mathrm{~Hz}, 6 \mathrm{H}, \mathrm{CH}_{3}\right) ;{ }^{13} \mathrm{C}-\mathrm{NMR}\left(75.5 \mathrm{MHz}, \mathrm{CDCl}_{3}, \delta\right): 159.2,131.6$, 125.4, 114.0, 63.6, 14.9; FTIR ( $\left.\mathrm{cm}^{-1}\right)$ : 3093, 3059 (w, aromatic C-H stretching), 2979, 2924, 2879 (w, aliphatic C-H stretching), 1613, 1519 (s, C=C stretching), 1252 (s, C-O$\mathrm{C}$ asymmetric stretching), 1049 ( $\mathrm{m}, \mathrm{C}-\mathrm{O}-\mathrm{C}$ symmetric stretching), 832 (s, aromatic $\mathrm{C}-\mathrm{H}$ out-of-plane bending). 


\subsection{Synthesis of 2,2-bis(3-chloromethyl-4-ethoxyphenyl)hexafluoropropane (BPAFCl)}

A mixture of BPAFEt (3.92 g, $10 \mathrm{mmol})$, paraformaldehyde $\left(2.50 \mathrm{~g}, 80 \mathrm{mmol}\right.$ of $\left.\mathrm{CH}_{2} \mathrm{O}\right)$, and $37 \%$ aqueous $\mathrm{HCl}(8.5 \mathrm{~mL}, 102 \mathrm{mmol})$ in acetic acid $(30 \mathrm{~mL})$ was stirred at $80{ }^{\circ} \mathrm{C}$ for $22 \mathrm{~h}$. The resulting mixture was then poured into distilled water and extracted with diethyl ether. The organic layer was washed several times with distilled water and dried over anhydrous magnesium sulfate. After solvent removal, BPAFCl was obtained as a colorless viscous liquid. Yield: 54\%; ${ }^{1} \mathrm{H}-\mathrm{NMR}\left(300 \mathrm{MHz}, \mathrm{CDCl}_{3}, \delta\right): 7.40-7.30(\mathrm{~m}, 4 \mathrm{H}$, Ar-H ), 6.85 (d, J = 9.0 Hz, 2H, Ar-H), $4.61\left(\mathrm{~s}, 4 \mathrm{H}, \mathrm{CH}_{2} \mathrm{Cl}\right), 4.13$ (q, J = $6.9 \mathrm{~Hz}, 4 \mathrm{H}$, $\left.\mathrm{OCH}_{2}\right), 1.47\left(\mathrm{t}, \mathrm{J}=6.9 \mathrm{~Hz}, 6 \mathrm{H}, \mathrm{CH}_{3}\right) ;{ }^{13} \mathrm{C}-\mathrm{NMR}\left(75.5 \mathrm{MHz}, \mathrm{CDCl}_{3}, \delta\right)$ : 157.2, 132.6, 131.7, 126.0, 125.1, 111.3, 64.2, 41.3, 14.8; FT-IR $\left(\mathrm{cm}^{-1}\right)$ : 3084, 3056 (w, aromatic C-H stretching), 2984, 2939, 2888 (w, aliphatic C-H stretching), 1614, 1509 (s, C=C stretching), 1250 (s, C-O-C asymmetric stretching $+\mathrm{CH}_{2} \mathrm{Cl}$ out-of-plane bending), 1044 (s, C-O-C symmetric stretching), 810 (s, aromatic C-H out-of-plane bending), 686 (s, $\mathrm{C}-\mathrm{Cl}$ stretching).

\subsection{Synthesis of 2,2-bis(4-ethoxy-3-triphenylphosphoniomethylphenyl)hexafluoropropane dichloride (BPAFP)}

A solution of BPAFCl $(3.81 \mathrm{~g}, 10 \mathrm{mmol})$ and triphenylphosphine $(5.82 \mathrm{~g}, 22 \mathrm{mmol})$ in anhydrous acetone $(50 \mathrm{~mL})$ was stirred and heated at reflux for $6 \mathrm{~h}$ in an argon atmosphere. After cooling the reaction mixture, the resulting white precipitate was filtered off, washed with diethyl ether several times and dried under vacuum. Yield: $90 \%$; mp: $220{ }^{\circ} \mathrm{C} ;{ }^{1} \mathrm{H}-$ NMR (300 MHz, $\mathrm{CDCl}_{3}, \delta$ ): 7.78-7.40 (m, 30H, P(Ph) $\left.)_{3}\right), 7.25$ (d, J = 9.0 Hz, 2H, Ar-H), $6.84(\mathrm{~s}, 2 \mathrm{H}, \mathrm{Ar}-\mathrm{H}), 6.65(\mathrm{~d}, \mathrm{~J}=9.0 \mathrm{~Hz}, 2 \mathrm{H}, \mathrm{Ar}-\mathrm{H}), 5.27\left(\mathrm{~d},{ }^{2} \mathrm{~J}_{\mathrm{H}-\mathrm{P}}=13.8 \mathrm{~Hz}, 4 \mathrm{H}, \mathrm{CH}_{2} \mathrm{P}\right)$, $3.57\left(\mathrm{q}, \mathrm{J}=6.9 \mathrm{~Hz}, 4 \mathrm{H}, \mathrm{OCH}_{2}\right), 1.03\left(\mathrm{t}, \mathrm{J}=6.9 \mathrm{~Hz}, 6 \mathrm{H}, \mathrm{CH}_{3}\right) ;{ }^{13} \mathrm{C}-\mathrm{NMR}(75.5 \mathrm{MHz}$, $\left.\mathrm{CDCl}_{3}, \delta\right): 157.3,135.1,133.8(\mathrm{~d}, \mathrm{~J}=9.7 \mathrm{~Hz}), 131.4,130.1(\mathrm{~d}, \mathrm{~J}=12.5 \mathrm{~Hz}), 128.7$, $117.8(\mathrm{~d}, \mathrm{~J}=85.8 \mathrm{~Hz}), 116.3(\mathrm{~d}, \mathrm{~J}=8.3 \mathrm{~Hz}), 111.2,64.0,24.3\left(\mathrm{~d},{ }^{1} \mathrm{~J}_{\mathrm{C}-\mathrm{P}}=49.1 \mathrm{~Hz}\right.$, $\mathrm{CH}_{2} \mathrm{P}$ ), 14.4; FT-IR $\left(\mathrm{cm}^{-1}\right.$ ): 3052 (w, aromatic C-H stretching), 2984, 2845, 2772 (w, aliphatic C-H stretching), 1611, 1507 (s, C=C stretching), 1249 (m, C-O-C asymmetric stretching), 1115 (s, P-C stretching), 1039 (s, C-O-C symmetric stretching), 743, 721, 691 (s, aromatic C-H out-of-plane bending), 507 (s, P-Cl stretching).

\subsection{Synthesis of poly[2,2-bis(4-ethoxyphenyl)hexafluoropropane-alt-1,4-divinylbenzene] (BPAF-PPV)}

To a stirred mixture of an equimolar amount of a BPAFP $(0.913 \mathrm{~g}, 1 \mathrm{mmol})$ and terephthaldicarboxaldehyde $(0.135 \mathrm{~g}, 1 \mathrm{mmol})$ in $10 \mathrm{~mL}$ of anhydrous THF, $10 \mathrm{~mL}$ of a $0.5 \mathrm{~mol} \mathrm{~L}^{-1} t$-BuOK solution in THF $(5 \mathrm{mmol})$ was added dropwise at room temperature under a nitrogen atmosphere. The reaction mixture was stirred for $24 \mathrm{~h}$ after the addition and then acified with $3 \%$ aqueous hydrochloric acid, poured into water and extracted with chloroform. The organic phase was washed with water, concentrated and then precipitated into methanol. A pale yellow powder was obtained, filtered and dried 
under vacuum for $24 \mathrm{~h}$. Yield: 58\%; ${ }^{1} \mathrm{H}-\mathrm{NMR}\left(300 \mathrm{MHz}, \mathrm{CDCl}_{3}, \delta\right)$ : 7.70-6.40 (br m, aromatic and vinylic $\mathrm{H}$ ), 4.20-3.80 (br m, $\mathrm{OCH}_{2}$ ), 2.19 (s, $\mathrm{Ar}-\mathrm{CH}_{3}$ end-group), 1.55-1.10 (br m, $\left.\mathrm{CH}_{3}\right) ;{ }^{13} \mathrm{C}-\mathrm{NMR}\left(75.5 \mathrm{MHz}, \mathrm{CDCl}_{3}, \delta\right.$ ): 157.5, 156.6, 137.2, 136.4, 132.3, 132.2, $130.8,131.9,131.6,130.6,129.7,129.8,129.6$, 129.2, 129.0, 128.7, 128.6, 127.0, 126.4, $126.2,125.7,125.5,125.4,125.0,124.9,124.8,123.4,114.1,111.2,110.1,64.1,63.6$, 16.6, 15.0, 14.9; ${ }^{19} \mathrm{~F}-\mathrm{NMR}\left(282 \mathrm{MHz}, \mathrm{CDCl}_{3}, \delta\right):-64.4$; FTIR $\left(\mathrm{cm}^{-1}\right): 3053(\mathrm{w}$, aromatic and vinylic $\mathrm{C}-\mathrm{H}$ stretching), 2982, 2932, 2881 (w, aliphatic $\mathrm{C}-\mathrm{H}$ stretching), 1607, 1504 (w-m, C=C stretching), 1253 ( $\mathrm{s}, \mathrm{C}-\mathrm{O}-\mathrm{C}$ asymmetric stretching), 1044 (m, C-O-C symmetric stretching), 806 (s, aromatic $\mathrm{C}-\mathrm{H}$ out-of-plane bending), 965 (m, trans $-\mathrm{HC}=\mathrm{CH}$ out-of-plane bending), 865 (w, cis- $\mathrm{HC}=\mathrm{CH}$ out-of-plane bending).

\subsection{Fabrication and characterization of diode}

The single-layer device was fabricated as a sandwich structure between aluminium (Al) cathode and indium tin oxide (ITO) anode. Polymer solution $\left(10 \mathrm{mg} \mathrm{mL}^{-1}\right.$ in chloroform) was spin-cast (2000 rpm) onto ITO glass to obtain a film with a thickness of about $60 \mathrm{~nm}$ after annealing at $40{ }^{\circ} \mathrm{C}$ for $1 \mathrm{~h}$. The thin aluminium layer $(150 \mathrm{~nm})$ was deposited as the cathode by thermal evaporation under $3 \times 10^{-6}$ Torr. The current-voltage (I-V) characteristic of the device was recorded with a digital oscilloscope Tektronix 5034.

\section{RESULTS AND DISCUSSION}

\subsection{Synthesis and structural characterization}

The polymer was obtained according to a four steps synthetic route as showed in scheme 2 . A new bischloromethyl aromatic derivative (BPAFCl) was synthesized from BPAF by direct chloromethylation of the benzene ring of the corresponding ethylated ether (BPAFEt) in a $\mathrm{HCl} /$ paraformadehyde/acetic acid system following a conventional described procedure [27]. Then, the bis(triphenylphosphonium) salt (BPAFP) was prepared by acetone reflux of BPAFCl in presence of triphenylphosphine. The synthesis of the polymer was carried out via a conventional Wittig reaction [28]. Thus, the addition of $t$-BuOK/THF solution to a suspension of BPAFP and terephthaldicarboxaldehyde produced BPAF-PPV which was isolated and purified by precipitation from methanol. The polymer was found to have good solubility in common organic solvents such as THF, chloroform, methylene chloride and so forth.

The polymer structure was well confirmed by NMR and FT-IR spectroscopic analysis. The ${ }^{1} \mathrm{H}-\mathrm{NMR}$ spectrum (figure 1) showed a broad peak between 7.70 and $6.40 \mathrm{ppm}$ assigned to phenylene and vinylene protons. The $\mathrm{CH}_{2} \mathrm{O}$ group and the methyl group appear in the ranges 4.20-3.80 ppm and 1.55-1.10 ppm, respectively. The absence of the aldehyde terminal groups was supported by the absence of the corresponding peak from the ${ }^{1} \mathrm{H}-\mathrm{NMR}$ spectrum (10 ppm). On the other hand, the appearance of a signal at $2.10 \mathrm{ppm}$ 

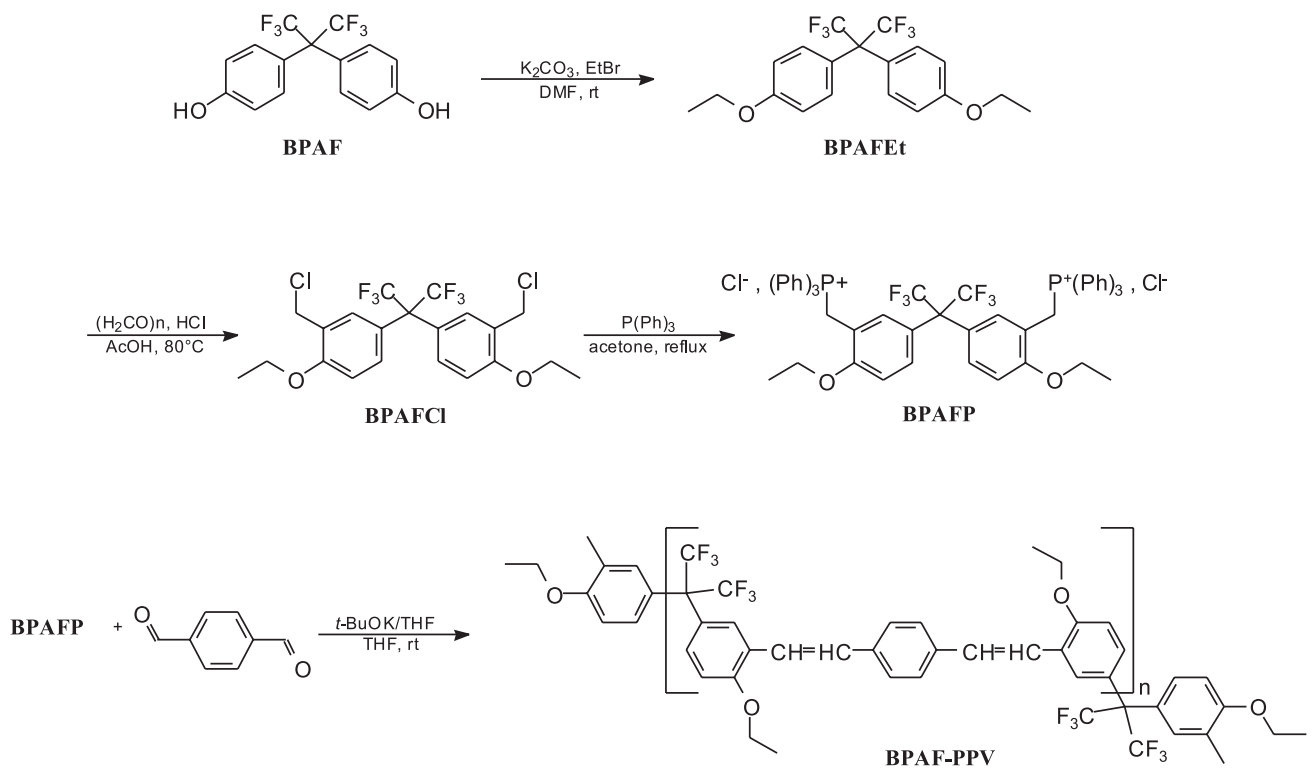

Scheme 2. Synthetic route to BPAF-PPV.

suggests a toluene methyl end-group $\left(\mathrm{Ar}-\mathrm{CH}_{3}\right)$. In fact, regarding the quantum efficiency, this feature is very significant knowing that carbonyl is a fluorescence-quencher group [29]. The FT-IR spectrum (figure 2) showed absorption bands due to aromatic and vinylic $\mathrm{C}-\mathrm{H}$ stretching at $3053 \mathrm{~cm}^{-1}$. The valence bands of the aliphatic $\mathrm{C}-\mathrm{H}$ groups are seen between 3000 and $2880 \mathrm{~cm}^{-1}$. The aromatic ring and vinylic $\mathrm{C}=\mathrm{C}$ stretching vibrations appear between 1610 and $1500 \mathrm{~cm}^{-1}$. The strong band at $1253 \mathrm{~cm}^{-1}$ is attributed to the asymmetric $\mathrm{C}-\mathrm{O}-\mathrm{C}$ vibration. The band at $1044 \mathrm{~cm}^{-1}$ is attributed to the symmetric $\mathrm{C}-\mathrm{O}-\mathrm{C}$ vibration. The out-of-plane vibration of the aromatic hydrogen shows a strong absorption at $806 \mathrm{~cm}^{-1}$. The spectrum showed the presence of both cis $\left(865 \mathrm{~cm}^{-1}\right)$ and trans $\left(965 \mathrm{~cm}^{-1}\right)$ vinylic absorptions [30]. Indeed, according to its chemical structure, the yilde used in this work can be classified as semi-stabilized yilde, and its normal Wittig reaction with aldehydes produces mixtures of $Z$ - and $E$ - configurations nonstereospecifically [31].

By comparing the ${ }^{1} \mathrm{H}-\mathrm{NMR}$ signal integration for toluene methyl terminal groups and $\mathrm{OCH}_{2}$ units, the degree of polymerization was estimated to be 8 , which gives a numberaverage molecular weight of $4570 \mathrm{~g} \mathrm{~mol}^{-1}$. The thermal stability of BPAF-PPV was investigated by TGA (figure 3) and DSC under ambient atmospheric conditions. The results showed a glass transition temperature $\left(T_{\mathrm{g}}\right)$ at $114^{\circ} \mathrm{C}$ and an onset thermal decomposition temperature at $263{ }^{\circ} \mathrm{C}$. No melting or other thermal events were seen before thermal decomposition, which suggested that the polymer was completely amorphous. 

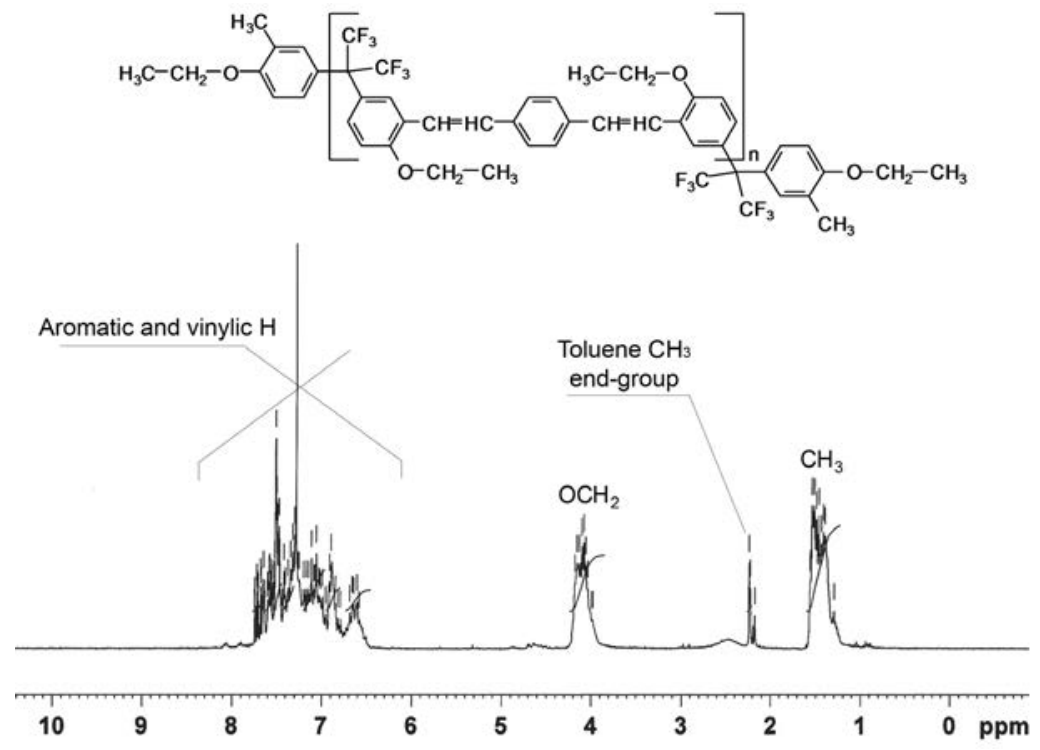

Figure 1. ${ }^{1} \mathrm{H}$-NMR spectrum of BPAF-PPV.

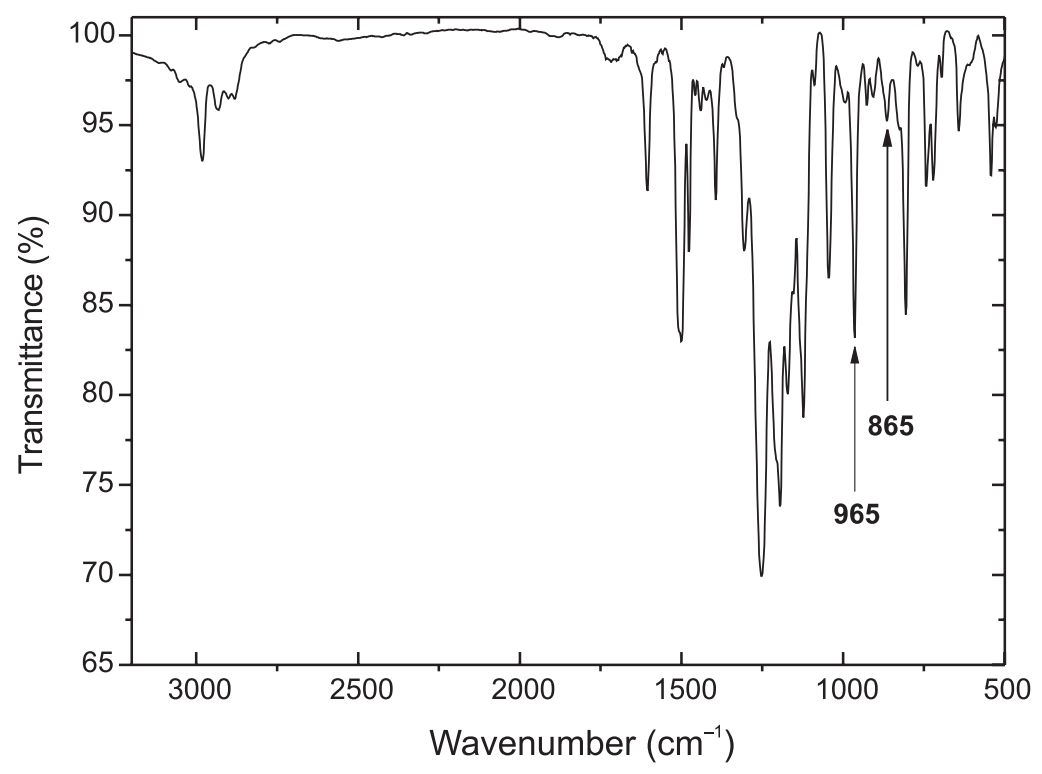

Figure 2. FT-IR spectrum of BPAF-PPV. 


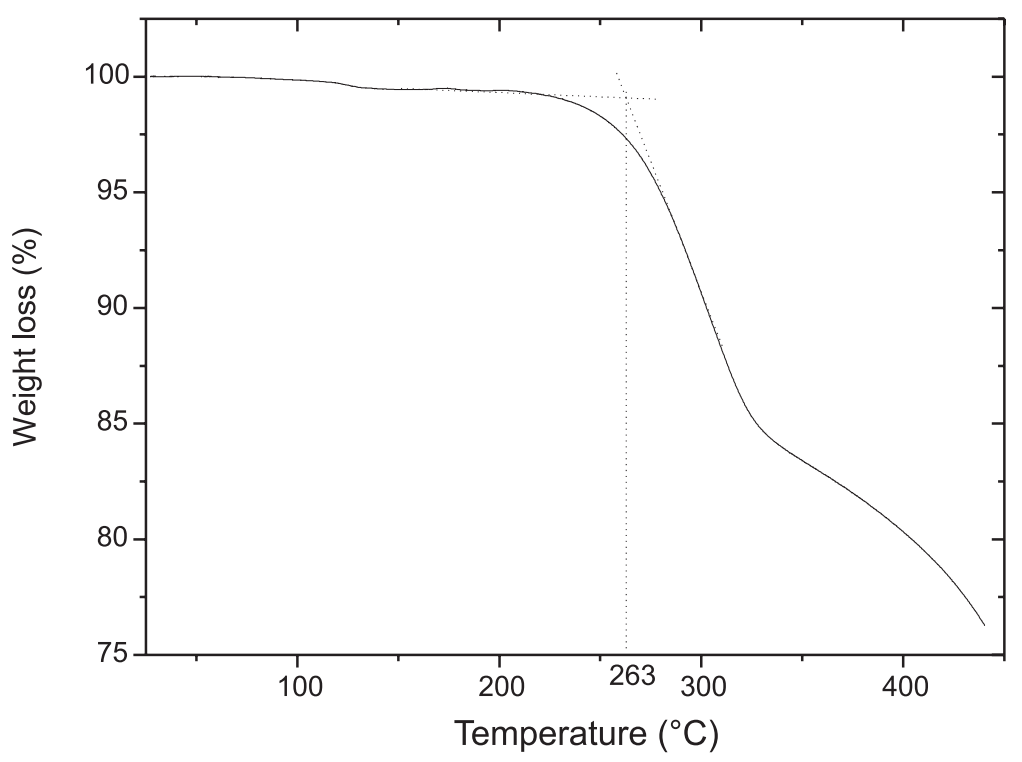

Figure 3. TGA thermogram of BPAF-PPV.

\subsection{Optical properties}

The UV-vis absorption and PL spectra of BPAF-PPV in dilute chloroform solution and as thin film are depicted in figure 4. The polymer solution exhibits an unstructured absorption spectrum with a maximum at $364 \mathrm{~nm}$ and an absorption coefficient of $2.18 \times$ $10^{4} \mathrm{M}^{-1} \mathrm{~cm}^{-1}$. It emits in the blue region with a narrow PPV-type emission spectrum [32] comporting two well-resolved bands at 412 and $437 \mathrm{~nm}$. The PL quantum efficiency $\left(\phi_{\mathrm{PL}}\right)$ of the polymer was determined in dilute chloroform solution by a relative method using quinine sulfate as standard [33] and its value was $83 \%$.

In comparison with BPA-PPV (table 1), BPAF-PPV showed slightly blue-shifted absorption and emission spectra. This is mainly caused by the inductive electronic effect of the trifluoromethyl withdrawing groups. We also noticed narrower UV-vis and PL spectra in the case of the fluorinated polymer. Such behavior is probably due to the steric hindrance of the bulky fluoromethyl groups which block the spacer segment conformational changes and reduce consequently the available vibrational and rotational freedom degrees [34]. This relatively important rigidity is probably the origin of the high PL efficiency observed for BPAF-PPV. In fact, the polymer BPA-PPV, containing the isopropylidene group as spacer, showed a significantly lower PL efficiency (44\%).

In the solid state, BPAF-PPV showed an absorption maximum at $353 \mathrm{~nm}$ with an absorption coefficient of about $6.34 \times 10^{4} \mathrm{~cm}^{-1}$. From the onset of film absorption (416 nm), the optical bandgap is calculated to be $2.98 \mathrm{eV}$. In comparison with the dilute solution, the UV-visible spectrum of the film was broader and the absorption onset was 


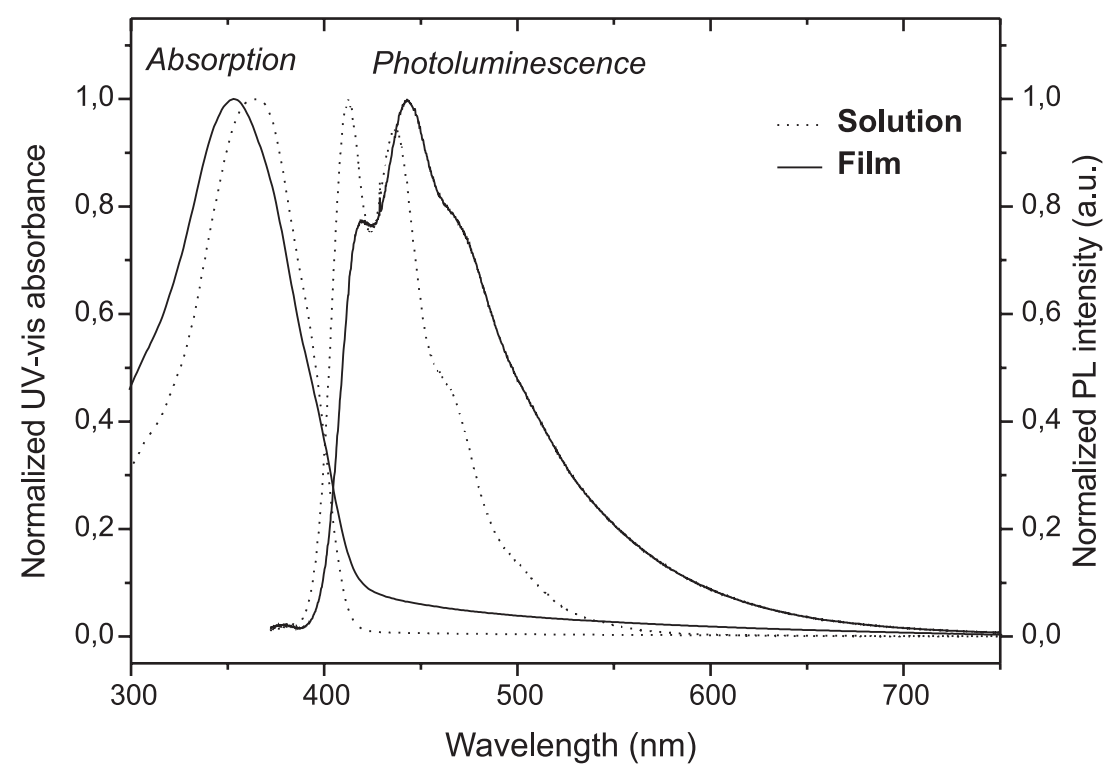

Figure 4. UV-vis absorption and PL spectra of BPAF-PPV in chloroform solution $\left(5 \times 10^{-5} \mathrm{~mol} \mathrm{~L}^{-1}\right.$ in absorption; $2 \times 10^{-7} \mathrm{~mol} \mathrm{~L}^{-1}$ in $\left.\mathrm{PL}\right)$ and as thin film (60 nm).

slightly red-shifted. Such behavior is in fact generally observed in $\pi$-conjugated polymers and was attributed to the $\pi-\pi$ stacking of conjugated segments and aggregates formation in the solid state [35]. These interactions also influence the film emission and a broad red-shifted PL spectrum was obtained as consequence to excimers formation [36].

In comparison with BPA-PPV, we noted lower red-shift and broadening values upon going from solution absorption and PL spectra to corresponding film spectra (table 1). These results suggest weaker $\pi-\pi$ interactions in BPAF-PPV film. The restriction of PPV units stacking is probably due to the steric repulsion of the bulky hexafluoroisopropylidene groups. Such solid state behavior limit the loss of film PL via $\pi-\pi$ stacking quenching processes [23] and makes BPAF-PPV a good candidate for high-efficiency PLEDs.

\subsection{HOMO and LUMO energy levels}

To investigate the redox behavior of BPAF-PPV and to estimate its highest occupied molecular orbital (HOMO) and lowest unoccupied molecular orbital (LUMO) energy levels, CV was applied to the polymer film. In fact, the knowledge of the HOMO and LUMO energy levels is of crucial importance to the selection of cathode and anode materials for PLED devices [37]. The use of CV analysis is of good reliability as the electrochemical processes probed thereby are similar to those involved in charge injection and transport processes in PLEDs [38]. BPAF-PPV was drop-coated onto ITO glass substrate and 
Table 1. Optical data of BPAF-PPV and BPA-PPV.

\begin{tabular}{|c|c|c|c|c|c|c|}
\hline \multicolumn{7}{|c|}{ In chloroform dilute solution } \\
\hline & \multicolumn{3}{|c|}{ Absorption } & \multicolumn{3}{|c|}{ Photoluminescence } \\
\hline $\begin{array}{l}\lambda_{\max } \\
(\mathrm{nm})\end{array}$ & $\begin{array}{c}\varepsilon_{\max } \\
\left(10^{4} \mathrm{M}^{-1} \mathrm{~cm}^{-1}\right) \\
\end{array}$ & $\begin{array}{c}\text { FWHM }^{\mathrm{a}} \\
(\mathrm{nm})\end{array}$ & $\begin{array}{l}\lambda_{\text {onset }} \\
(\mathrm{nm})\end{array}$ & $\begin{array}{l}\lambda_{\max } \\
(\mathrm{nm})\end{array}$ & $\begin{array}{c}\text { FWHM }^{\mathrm{a}} \\
(\mathrm{nm})\end{array}$ & $\begin{array}{l}\phi_{\mathrm{PL}}^{\mathrm{b}} \\
(\%)\end{array}$ \\
\hline $\begin{array}{l}\text { BPAF- } 364 \\
\text { PPV }\end{array}$ & 2.18 & 70 & 411 & $\begin{array}{c}412 ; 437 ; \\
465^{c}\end{array}$ & 55 & 83 \\
\hline $\begin{array}{l}\text { BPA- } 369 \\
\text { PPV }\end{array}$ & 2.48 & 79 & 419 & $\begin{array}{c}420 ; 445 ; \\
478^{c}\end{array}$ & 63 & 44 \\
\hline & \multicolumn{6}{|c|}{ As thin film } \\
\hline & \multicolumn{3}{|c|}{ Absorption } & \multicolumn{3}{|c|}{ Photoluminescence } \\
\hline $\begin{array}{l}\lambda_{\max } \\
(\mathrm{nm})\end{array}$ & $\begin{array}{c}\varepsilon_{\max } \\
\left(10^{4} \mathrm{~cm}^{-1}\right)\end{array}$ & $\begin{array}{c}\text { FWHM }^{\mathrm{a}} \\
(\mathrm{nm})\end{array}$ & $\begin{array}{l}\lambda_{\text {onset }} \\
(\mathrm{nm})\end{array}$ & $\begin{array}{l}\lambda_{\max } \\
(\mathrm{nm})\end{array}$ & $\begin{array}{c}\text { FWHM }^{\mathrm{a}} \\
(\mathrm{nm})\end{array}$ & \\
\hline $\begin{array}{l}\text { BPAF- } 353 \\
\text { PPV }\end{array}$ & 6.34 & 97 & 416 & $\begin{array}{c}420 ; 443 ; \\
473^{(\mathrm{c})}\end{array}$ & 88 & \\
\hline $\begin{array}{l}\text { BPA- } 364 \\
\text { PPV }\end{array}$ & 7.78 & 109 & 428 & $\begin{array}{r}428 ; 453 ; \\
484 ; 510^{(\mathrm{c})} \\
\end{array}$ & 161 & \\
\hline
\end{tabular}

${ }^{a}$ Spectrum full width half maximum.

${ }^{\mathrm{b}} \mathrm{PL}$ quantum yield measured using quinine sulfate as the standard $\left(\phi_{\mathrm{PL}}=0.546\right.$ in $\left.0.5 \mathrm{~mol} \mathrm{~L}^{-1} \mathrm{H}_{2} \mathrm{SO}_{4}\right)$.

${ }^{c}$ Shoulder.

scanned both positively and negatively in $(\mathrm{n}-\mathrm{Bu})_{4} \mathrm{NClO} /$ acetonitrile solution. As shown in the cyclic voltammogram depicted in figure 5 , the onset of oxidation $\left(\mathrm{V}_{\text {onset-ox }}\right)$ was found to occur at $1.17 \mathrm{~V}$ and the onset of reduction $\left(\mathrm{V}_{\text {onset-red }}\right)$ was at $-1.91 \mathrm{~V}$ (vs SCE). According to an empirical method [39] and by assuming that the energy level of the ferrocene/ferrocenium is $4.8 \mathrm{~V}$ below the vacuum level, the HOMO and LUMO energy levels can be calculated as follows:

$$
\begin{aligned}
E_{\mathrm{HOMO}}(\mathrm{IP}, \text { ionization potential }) & =-\left(\mathrm{V}_{\text {onset-ox }}-\mathrm{V}_{\mathrm{FOC}}+4.8\right) \mathrm{eV} \\
E_{\mathrm{LUMO}}(\mathrm{EA}, \text { electron affinity }) & =-\left(\mathrm{V}_{\text {onset-red }}-\mathrm{V}_{\mathrm{FOC}}+4.8\right) \mathrm{eV}
\end{aligned}
$$

where $\mathrm{V}_{\mathrm{FOC}}$ is a $0.55 \mathrm{~V}$, the ferrocene half-wave potential measured versus SCE. Thus, $E_{\mathrm{HOMO}}, E_{\mathrm{LUMO}}$ and the electrochemical bandgap values were estimated to be $-5.42,-2.34$ and $3.08 \mathrm{eV}$, respectively. The slight difference between the bandgaps obtained from the optical method and from electrochemical analysis has been previously reported in some other conjugated polymers and was attributed to the interface barrier between the polymer film and the electrode surface [38]. In fact, the optical value corresponds to the pure bandgap between the valence band and the conduction band, while the electrochemical value may be the results of the optical bandgap coupled with the interface barrier for charge injection, which makes it larger. 


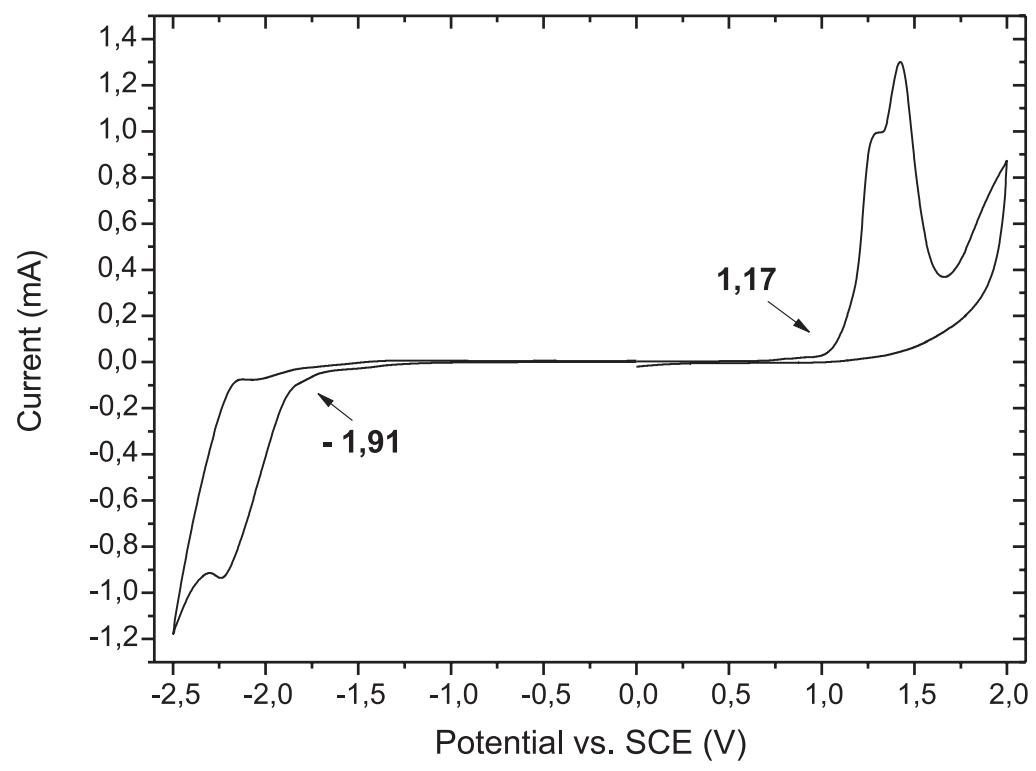

Figure 5. Cyclic voltammogram of BPAF-PPV film coated on an ITO electrode in $0.1 \mathrm{~mol} \mathrm{~L}^{-1}$ $(\mathrm{n}-\mathrm{Bu})_{4} \mathrm{ClO} /$ acetonitrile at scanning rate of $50 \mathrm{mV} \mathrm{s}^{-1}$.

\subsection{Electrical properties}

A single-layer device with the configuration ITO/BPAF-PPV/Al has been fabricated to investigate the current-voltage (I-V) characteristic of the polymer. As shown in figure 6, the I-V curve indicates typical diode behavior with a relatively low turn-on voltage of 3.0 V. Nevertheless, no electroluminescence could be recorded for this simple device. The reason is probably the unbalanced charge injection which increases the probability of excitons radiationless quenching at the electrode/polymer interface [40]. Indeed, the energy barrier for hole injection from ITO (work function: $-4.60 \mathrm{eV}$ ) into BPAF-PPV film ( $E_{\mathrm{HOMO}}:-5.42 \mathrm{eV}$ ) was $0.82 \mathrm{eV}$. In return, the barrier for electron injection from $\mathrm{Al}$ (work function: $-4.20 \mathrm{eV}$ ) into the polymer $\left(E_{\mathrm{LUMO}}:-2.34 \mathrm{eV}\right.$ ) was $1.86 \mathrm{eV}$. Thus, we guess that the device turn-on voltage indicates the threshold of a hole-governed unipolar injection. Work is in progress to build electroluminescent multilayer devices.

\section{CONCLUSION}

A new soluble confined PPV-type polymer (BPAF-PPV) has been synthesized and characterized. The well-defined degree of conjugation in the oligomeric PPV segment results in a chromophore that exhibits blue photoluminescence in thin film. Limited interchain interactions were observed in the solid state, due to presence of bulky packing disrupting 


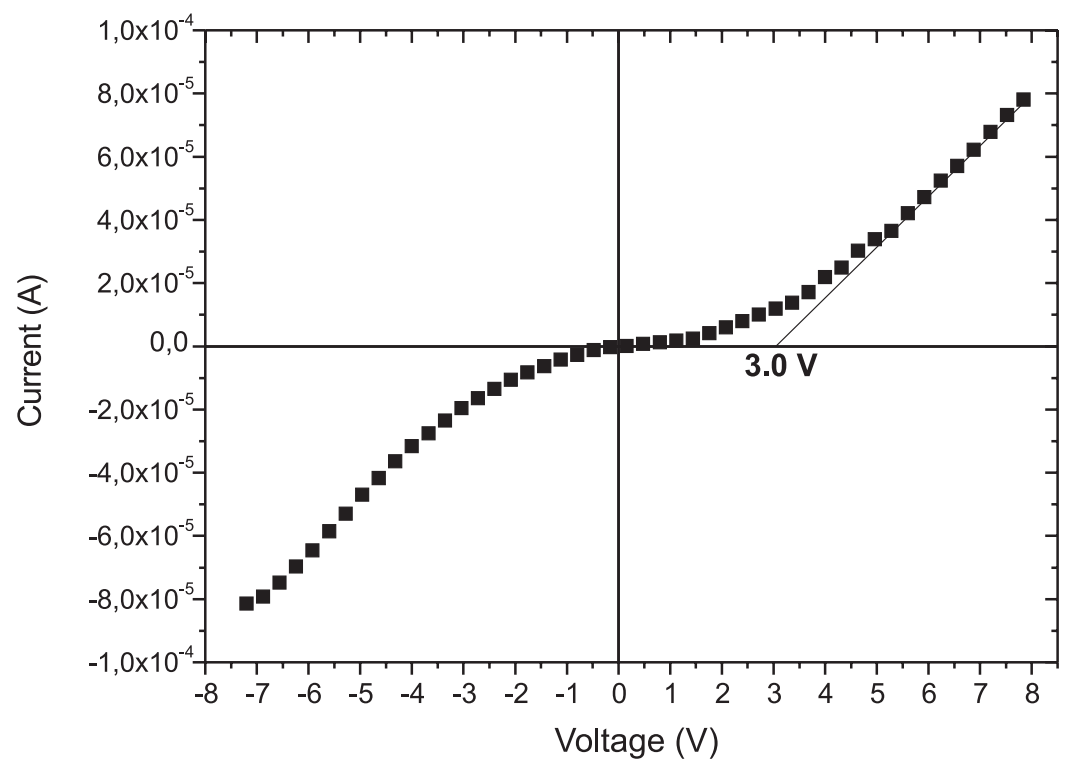

Figure 6. Current-voltage curve of ITO/BPAF-PPV/AI diode.

trifluoromethyl groups, and a narrow emission spectrum was obtained. The photoluminescence quantum efficiency was determined in dilute solution and was about $83 \%$. The I-V characteristic of the device with an ITO/BPAF-PPV/Al configuration demonstrates typical diode behavior and a relatively low turn-on voltage of $3.0 \mathrm{~V}$. In further work, this new blue-photoluminescent semi-conducting polymer will be characterized in different light-emitting-device configurations.

Acknowledgements. This work was partially supported by the contact CMCU code 05S1304. The authors thank Dr Rafik Ben Chaâbane (Laboratoire de Physique et Chimie des Interfaces, Faculty of Sciences, Monastir) for the electrical measurements and Madam Amna Debbebi (Faculty of Sciences, Monastir) for NMR measurements.

\section{NOTE}

1. Author to whom correspondence should be addressed: mustapha.majdoub@fsm.rnu.tn

\section{REFERENCES}

[1] Burroughes, J.H., Bradley, D.D.C., Brown, A.R., Marks, R.N., Mackay, K., Friend, R.H., Burn, P.L. and Holmes, A.B. (1990). Light-Emitting Diodes based on Conjugated Polymers, Nature, 347: 539-541.

[2] Kraft, A., Grimsdale, A.C. and Holmes, A.B. (1998). Electroluminescent Conjugated Polymers-Seeing Polymers in a New Light, Angew Chem Int Ed Eng, 37: 402-428.

[3] Akcelrud, L. (2003). Electroluminescent Polymers, Prog Polym Sci, 28: 875-962. 
[4] Segura, J.L. (1998). The Chemistry of Electroluminescent Organic Materials, Acta Polym., 49: 319-344.

[5] Xiang, D., Shen, Q., Zhang, S. and Jiang, X. (2003). Synthesis and Characterization of Novel Soluble Alternating Copoly(phenylene vinylene) Derivative for Light-Emitting Electrochemical Cell, J. Appl. Polym. Sci., 88: 1350-1356.

[6] Sun, Q., Yang, C., Wang, H., He, G. and Li, Y. (2002). Polymer Light-Emitting Electrochemical Cell based on a Block Copolymer Containing Tri(ethyleneoxide) Spacers, Polym. Adv. Technol., 13: 663-669.

[7] Murphy, A.R. and Fréchet, J.M.J. (2007). Organic Semiconducting Oligomers for Use in Thin Film Transistors, Chem. Rev., 107: 1066-1096.

[8] Segura, J.L., Martin, N. and Guldi, D.M. (2005). Materials for Organic Solar Cells: the C60/ $\pi$-Conjugated Cligomer Approach, Chem. Soc. Rev., 34: 31-47.

[9] Gunes, S., Neugebauer, H. and Sariciftci, N.S. (2007). Conjugated Polymer-Based Organic Solar Cells, Chem. Rev., 107: 1324-1338.

[10] Thomas III, S.W., Joly, G.D. and Swager, T.M. (2007). Chemical Sensors Based on Amplifying Fluorescent Conjugated Polymers, Chem. Rev., 107: 1339-1386.

[11] Lange, U., Roznyatovskaya1, N.V. and Mirsky, V.M. (2008). Conducting Polymers in Chemical Sensors and Arrays, Anal. Chim. Acta, 614: 1-26.

[12] Kim, D.Y., Cho, H.N. and Kim, C.Y. (2000). Blue Light Emitting Polymers, Prog. Polym. Sci., 25: 1089-1139.

[13] Ohmori, Y., Uchida, K., Muro, K. and Yoshino, K. (1991). Blue Electroluminescent Diodes Utilizing Poly(alkylfluorene), Jpn. J. Appl. Phys., 30: 1941-1943.

[14] Lee, J.-H. and Hwang, D.-H. (2003). Alkoxyphenyl-Substituted Polyfluorene: a Stable Blue-LightEmitting Polymer with Good Solution Processability, Chem. Commun., 22: 2836-2837.

[15] Edwards, A., Blumstengel, S., Sokolik, I., Dorsinville, R., Yun, H., Kwei, T.K. and Okamoto, Y. (1997). Blue Photo- and Electroluminescence from Poly(benzoyl-1,4-phenylene), Appl. Phys. Lett., 70: 298-300.

[16] Andersson, M.R., Berggren, M., Gustafsson, G., Hjertberg, T., Inganäs, O. and Wennerström, O. (1995). Synthesis of Poly(alkylthiophenes) for Light-Emitting Diodes, Synth. Met., 71: 2183-2184.

[17] Brown, A.R., Burn, P.L., Bradley, D.D.C., Friend, R.H., Kraft, A. and Holmes, A.B. (1992). Blue-Shifted Electroluminescence from a Stable Precursor to Poly( $p$-phenylene vinylene), Mol. Cryst. Liq. Cryst., 216: 111-116.

[18] Liao, L., Pang, Y., Ding, L. and Karasz, F.E. (2001). Blue-Emitting Soluble Poly(m-phenylenevinylene) Derivatives, Macromolecules, 34: 7300-7305.

[19] Gowri, R., Mandal, D., Shivkumar, B. and S. Ramakrishnan. (1998). Synthesis of Novel Poly[(2,5dimethoxy-p-phenylene)vinylene. Precursors Having Two Eliminatable Groups: An Approach for the Control of Conjugation Length, Macromolecules, 31: 1819-1826.

[20] Hay, M. and Klavetter, F.L. (1995). Aliphatic Phenylene Vinylene Copolymers: Tuning the Color of Luminescence through Co-monomer Feed Ratios, J. Am. Chem. Soc. 117: 7112-7118.

[21] Yang, Z., Sokolik, I. and Karasz, F.E. (1993). A Soluble Blue-Light-Emitting Polymer, Macromolecules, 26: $1188-1190$

[22] Liau, C.Y., Gan, Y.Y., Zhou, Y., Lam, Y.L. and Gan, L.H. (2000). Studies of an Intrinsically Soluble Copolymer with Well-Defined Alternating Substituted $p$-Phenylenevinylene and Hexanedioxy Blocks, Polymer, 41: 7339-7346.

[23] Rothberg, L.J., Yan, M., Papadimitrakopoulos, F., Galvin, M.E., Kwock, E.W. and Miller, T.M. (1996). Photophysics of Phenylenevinylene Polymers, Synth. Met., 80: 41-58.

[24] Zheng, S., Shi, J. and Mateu, R. (2000). Novel Blue Light Emitting Polymer Containing an Adamantane Moiety, Chem. Mater., 12: 1814-1817.

[25] Amrutha, S.R. and Jayakannan, M. (2007). Structure Control of $\pi$-Conjugated Polymers for Enhanced Solid-State Luminescence: Synthesis and Liquid Crystalline and Photophysical Properties of New Bulky Poly(p-phenylenevinylene)s and Oligo(phenylenevinylene)s Bearing Tricyclodecane Pendants, Macromolecules, 40: 2380-2391.

[26] Jaballah, N., Trad, H., Majdoub, M., Jouini, M., Roussel, J. and Fave, J.-L. (2006). Synthesis and Characterization of New Blue-Photoluminescent Copolymer Derived from Bisphenol A, J. Appl. Polym. Sci., 99: 2997-3004.

[27] Trad, H., Majdoub, M. and Davenas, J. (2006). Soluble PPVs with Few Structural Defects: Synthesis and Characterization, Mater. Sci. Eng. C, 26: 334-339. 
[28] Jaballah, N., Majdoub, M., Fave, J.-L., Barthou, C., Jouini, M. and Tanguy, J. (2008). New Confined p-Phenylenevinylene (PPV)-type Polymer Analogue of Poly(phenylene sulfide), Eur. Polym. J., 44: 28862892.

[29] Yang, M., Rothberg, L.J., Papadimitrakopoulos, F., Galvin, M.E. and Miller, T.M. (1994). Defect Quenching of Conjugated Polymer Luminescence, Phys. Rev. Lett., 73: 744-747.

[30] Liao, L., Pang, Y., Ding, L. and Karasz, F.E. (2001). Synthesis, Characterization and Luminescence of Poly[(m-phenylenevinylene)-alt-(1,4-dibutoxy-2,5-phenylenevinylene)] with Different Content of cis- and trans-Olefins, Macromolecules, 34: 6756-6760.

[31] Ndayikengurukiye, H., Jacobs, S., Tachelet, W., Van Der Looy, J., Pollaris, A., Geise, H.J., Ciaeys, M., Kauffmann, J.M. and Janietz S. (1997). Alkoxylated $p$-Phenylenevinylene Oligomers: Synthesis and Spectroscopic and Electrochemical Properties, Tetrahedron, 53: 13811-13828.

[32] Ton-That, C., Stockton, G., Phillips, M.R., Nguyen, T.-P., Huang, C.H. and Cojocaru, A. (2008). Luminescence Properties of Poly(phenylene vinylene) Derivatives, Polym. Int., 57: 496-501.

[33] Feng, L. and Chen, Z. (2005). Synthesis and Photoluminescent Properties of Polymer Containing Perylene and Fluorene Units, Polymer, 46: 3952-3956.

[34] Henari, F.Z., Manaa, H., Kretsch, K.P., Blau, W.J., Rost, H., Pfeiffer, S., Teuschel, A., Tillmann, H. and Horhold, H.H. (1999). Effective Stimulated Emission and Excited State Absorption Measurements in the Phenylene-Vinylene Oligomer (1,4-bis-(alpha-cyanostyryl)-2,5-dimethoxybenzene)), Chem. Phys. Lett., 307: 163-166.

[35] Peng, K.-Y., Chen, S.-A., Fann, W.-S., Chen, S.-H. and Su, A.-C. (2005). Well-Packed Chains and Aggregates in the Emission Mechanism of Conjugated Polymers, J. Phys. Chem. B, 109: 9368-9373.

[36] Huang, Y.F., Shiu, Y.J., Hsu, J.H., Lin, S.H., Su, A.C., Peng, K.Y., Chen, S.A. and Fann, W.S. (2007). Aggregate versus Excimer Emissions from Poly(2,5-di- $n$-octyloxy-1,4-phenylenevinylene), J. Phys. Chem. C, 111: 5533-5540.

[37] Fan, B., Sun, Q., Song, N., Wang, H., Fan, H. and Li, Y. (2006). Electroluminescent Properties of a Partially-Conjugated Hyperbranched Poly(p-phenylene vinylene), Polym. Adv. Technol., 17: 145-149.

[38] Cheng, M., Xiao, Y., Yu, W.-L., Chen, Z.-K., Lai, Y.-H. and Huang W. (2000). Synthesis and Characterization of a Cyano-Substituted Electroluminescent Polymer with Well-Defined Conjugation Length, Thin Solid Films, 363: 110-113.

[39] Bredas, J.L., Silbey, R., Bordeaux, D.S. and Chance, R.R. (1983). Chain-Length Dependence of Electronic and Electrochemical Properties of Conjugated Systems: Polyacetylene, Polyphenylene, Polythiophene, and Polypyrrole, J. Am. Chem. Soc., 105: 6555-6559.

[40] Blom, P.W.M., Vissenberg, M.C.J.M. (2000). Charge Transport in Poly(p-phenylene vinylene) LightEmitting Diodes, Mater. Sci. Eng., R, 27: 53-94. 